\title{
LEGISLATION, REPUGNANCY AND THE DiSALLOWANCE OF COLONIAL LAWS: THE LEGAL STRUCTURE OF EMPIRE AND LLOYD'S CASE (1844)
}

\section{Damen Ward*}

\begin{abstract}
The imperial government had the ability to disallow New Zealand colonial ordinances that were "repugnant to the laws of England". "Repugnancy" did not operate as a clear legal criterion; the British government could take into account a range of political factors. Instructions to governors were sometimes used to avoid potential legal questions about the impact of disallowance. Henry Samuel Chapman's judgment in Lloyd's case (1844) provides a basis for exploring the legal, administrative and political practices surrounding the disallowance of colonial laws. Judges' and officials' views on how disallowance took effect show the interaction between political authority, political communication, and legal institutions in a Crown Colony. Lloyd, and Chapman's extrajudicial writing about repugnancy, help illustrate changing colonial views of the imperial constitution across the mid-nineteenth century. The case therefore shows how New Zealand legal history can contribute to a wider historiography of empire.
\end{abstract}

\section{INTRODUCTION}

By the 1840s a range of commentators on colonial affairs saw legislation as a key means of adapting English law to colonial circumstances. ${ }^{1}$ Colonial legislative councils, however, had limited

* Crown Counsel, Crown Law Office, and member of the New Zealand Lost Cases Project, Victoria University of Wellington. The views in this article are my own; nothing in this article is necessarily the view of the Crown Law Office. My thanks to Mary-Camillus Dale, Shaunnagh Dorsett, Ned Fletcher, Robert Kirkness, John McLaren, Brent Parker and Megan Simpson. Thank you to the New Zealand Law Foundation for its support of the New Zealand Lost Cases Project. All New Zealand Supreme Court cases referred to in this article are reported in the New Zealand's Lost Cases database <www.victoria.ac.nz/law/nzlostcases>. This article also draws on research completed for my DPhil thesis, "The Politics of Jurisdiction. 'British' Law, Indigenous Peoples and Colonial Government in South Australia and New Zealand, c 1834-60" (DPhil Thesis, Oxford University, 2003).

1 Keith Sinclair "The Aborigines Protection Society and New Zealand: A Study in Nineteenth Century Opinion" (MA Thesis, Auckland University College, 1946) at 27 and 33; Saxe Bannister Humane Policy; 
capacity. The imperial government retained the ability to disallow colonial ordinances which were "repugnant to the laws of England". This paper explores how the British government assessed Crown Colony laws against this standard in the 1840s. "Repugnancy" did not operate as a clear legal criterion; the British government could take into account a range of political factors. Instructions to governors were sometimes used to avoid potential legal questions about the impact of disallowance. Judges' and officials' views on how disallowance took effect in a colony show the interaction between political authority, political communication, and legal institutions in a Crown Colony.

In the Matter of Lloyd (Lloyd) shows the ambiguity that surrounded repugnancy doctrine, and provides a new perspective on the way colonial understandings of the imperial constitution shifted across the mid-19th century. I use Lloyd as a reference point. I do not think Lloyd's importance lies in the particular result or the facts of the case. The case is important because it highlights elements of the interaction between colonial law and government that have received little attention in recent historiography. Importantly, Lloyd provides insight into Henry Samuel Chapman's own thought about disallowance and repugnancy, and how it may have changed over time. Chapman, the second judge appointed to New Zealand, remains best known for a single decision, $R v$ Symonds. $^{2}$ His broader approach to the operation of colonial law, and his place in imperial legal and political networks, has only recently received more detailed attention. ${ }^{3}$ Lloyd was Chapman's first civil decision in New Zealand, and the only repugnancy disallowance case in New Zealand in the 1840s. By considering the broader context of the case we can see that Chapman was well aware of the significance of the law and policy surrounding disallowance and repugnancy. This might seem unsurprising given Chapman's close involvement in Canadian and British debates over colonial

or, Justice to the Aborigines of New Settlements (Thomas and George Underwood, London, 1830); Montague Hawtrey "Exceptional laws in favour of the Natives of New Zealand", Appendix A in EG Wakefield The British Colonization of New Zealand (John W Parker, London, 1837) (British Colonization); D Coates, Rev John Beecham and Rev William Ellis, evidence to Select Committee on Aborigines (6 June 1836) Great Britain Parliamentary Papers (GBPP) (1836) vii (538) 481-492, 503-504, and 515-517. EG Wakefield British Colonization at 27-28; Arthur James Johnes Legislation Applied to Infant Colonies. A Letter Addressed to the Commissioners of the Association for the British Colonization of New Zealand (H Hooper, London, 1838) at 7-19 and 26-28.

$2 \quad R v$ Symonds (1847) NZPCC 387. Note the explanation of Symonds in $R v M^{\prime}$ Donald, SC Wellington, 20 January 1849 per Chapman J in "Civil trials No.6", 1845-6, MS-0411/007, Hocken Library, University of Otago (HL), 149-160. Mark Hickford "'Vague Native Rights': British Imperial Policy on Native Title and Custom in New Zealand, 1837-53" (2010) 38 Journal of Inperial and Commonwealth History 175; see also, Mark Hickford "Settling some Important Principles of Colonial Law: Three 'Forgotten' Cases of the 1840s" (2004) 35 VUWLR 1.

3 Shaunnagh Dorsett "Sworn on the Dirt of Graves: Sovereignty, Jurisdiction and the Judicial Abrogation of 'Barbarous' Customs in New Zealand in the 1840s" (2009) 30 Journal of Legal History 175; Shaunnagh Dorsett "Sovereignty as Governance in the Early New Zealand Crown Colony Period" in Shaunnagh Dorsett and Ian Hunter (eds) Law and Politics in British Colonial Thought. Transpositions of Empire (Palgrave, London, 2010); Hickford "Important Principles", ibid; Hickford, "Vague Native Rights", ibid. 
government prior to his appointment to the bench, but the decision indicates how Chapman chose to address such issues in a judicial context. ${ }^{4}$ Lloyd's case therefore gives an example of the way law and government interacted in the 1840 s at both colonial and imperial levels.

The article has three sections. First, I outline the background to the case and the questions about disallowance that it generated. Second, I explore how disallowance of colonial legislation by the British government operated in practice. My interest is in the machinery of review, and the way political or administrative factors could shape how an ordinance was treated. Third, I discuss briefly what this might show us about how the courts in the 1840s viewed the relationship between legislation and the prerogative. I look at Chapman's later writing on repugnancy, and the role of legislation and Crown authority in his account of the relationship between the Crown and the colonies.

\section{LLOYD'S CASE}

Mr Lloyd was a baker and confectioner. ${ }^{5}$ He purchased goods from merchants, Boulcott and Stokes. ${ }^{6} \mathrm{He}$ was unable to pay the debt of $£ 83$ 15s. We know almost nothing about the circumstances of the case, except that Lloyd was found liable for the debt. ${ }^{7}$ There are no records relating to any subsequent proceedings to have Mr Lloyd's goods seized to satisfy the debt, or to have the court issue a writ capias ad satisfaciendum to have Mr Lloyd imprisoned for his default. This last step does seem to have occurred, though it is not clear exactly when. ${ }^{8}$ All the proceedings in the case were taken in the Supreme Court.

4 Chapman was formerly a Canadian newspaper editor, London agent for the Lower Canada Legislative Assembly, and an associate of leading radical reformers, "colonial reform" lobbyists and parliamentarians in the 1830s. DG Edwards "Chapman, Henry Samuel 1803-1881" Dictionary of New Zealand Biography <www.dnzb.govt.nz>; RS Neale "Chapman, Henry Samuel (1803-1881)" Australian Dictionary of Biography (Melbourne, Melbourne University Press, 1969) vol 3 at 380-382. Dorsett "Sworn on the Dirt", ibid, at 181-183.

$5 \quad$ New Zealand Colonist (Wellington, 3 February 1843) at 1. Lloyd is the only man of that name in the Wellington jurors roll in February 1845; New Zealand Gazette and Wellington Spectator (Wellington, 8 February 1845) supplement at 1.

6 Robert Stokes (c 1810-1880) was the proprietor of the New Zealand Gazette and Wellington Spectator Stokes was also employed as a New Zealand Company surveyor. Joseph Boulcott was a merchant on Te Aro flat. His father, John Boulcott, was a director of the New Zealand Company. Joseph's brother, Almon, later farmed in the Hutt Valley; a military stockade built on the farm was attacked by Te Mamaku's troops in May 1846: Ian Wards, The Shadow of the Land, (Wellington, Government Publishers, 1968) at 266-267.

7 Boulcott $v$ Lloyd, Supreme Court Wellington, 3 October 1843 per Martin CJ reported in New Zealand Gazette and Wellington Spectator (Wellington, 18 October 1843) at 3.

8 Imprisonment following judgment was "a final remedy". Under English law, the debtor remained in custody until they paid the debt, were declared bankrupt, or were released by their creditors. Once released, no further action to enforce the debt was permitted. Bruce Kercher Debt, Seduction and Other Disasters: The Birth of Civil Law in Convict New South Wales (Sydney, Federation Press, 1996) at 180-185. 
The Court was created by the Supreme Court Ordinance $1841 .{ }^{9}$ Mr Lloyd was in the custody of the Sheriff. However, the Ordinance was disallowed by the British government. For lawyers, a series of interesting questions can arise in such situations. If the law is disallowed, is it invalid from the moment of disallowance onwards, or does the disallowance declare the ordinance never to have been a valid law at all. Such questions have practical implications; if the Supreme Court Ordinance was void ab initio (from the outset), what was the status of transactions or orders that had already been made under it? What was the position of the Sheriff, who had imprisoned Mr Lloyd? Some problems might arise even if the Ordinance was merely voidable (that is, it was invalid from the disallowance point on); what happened to partly heard cases, or partly completed transactions? And importantly for Mr Lloyd, when did disallowance by the Crown take effect? Consider the situation with the 1841 Ordinance. The disallowance was signalled by despatches signed in London on 1 November 1842 and 9 January 1843. A further despatch dated 31 January 1843 detailed the reasons for disallowance and gave instructions about announcing the decision. ${ }^{10}$ That despatch arrived in Wellington on 4 September 1843 and reached the capital, Auckland, sometime in midSeptember. Governor FitzRoy had read it by 26 September. ${ }^{11}$ Mr Lloyd had judgment against him on 18 October. FitzRoy mentioned the disallowance in a speech to the Legislative Council on 9 January 1844. (FitzRoy gave no indication of the grounds of disallowance, but indicated that a replacement ordinance would be proposed during that session). ${ }^{12}$ The replacement law, the Supreme Court Ordinance 1844, was duly passed, and received the Governor's assent on 13 January $1844 .{ }^{13}$ The Governor's speech to the Council was reported in Wellington on 31 January $1844 .{ }^{14}$

By February 1844, Lloyd had hired counsel, Mr Holyrod. ${ }^{15}$ Holyrod applied to have Lloyd released from custody on the grounds that the disallowance of the Supreme Court Ordinance meant Lloyd's detention was unlawful. Chapman J heard the case in chambers on the second day of the first Supreme Court session in Wellington. On the first day, the new ordinance had been read out in Court. ${ }^{16}$

9 Supreme Court Ordinance 18415 Vict No 1.

10 Lord Stanley to FitzRoy (31 January 1843), Archives New Zealand, Wellington (ANZ), G1/7.

11 Notations on Lord Stanley to FitzRoy (31 January 1843), ANZ G1/7.

12 New Zealand Gazette and Wellington Spectator (Wellington, 31 January 1844) at 3 and (17 February 1844) at 4 .

13 Supreme Court Ordinance 184418447 Vict No 1.

14 New Zealand Gazette and Wellington Spectator (Wellington, 31 January 1844) at 3.

15 See HTE Holt "Holroyd, Arthur Todd (1806-1887)" Australian Dictionary of Biography, above n 4, vol 4 at 411-412, available at <http://adbonline.anu.edu.au>.

16 The new ordinance did not appear in the Wellington press until 17 February 1844, the day Chapman gave his decision. However, Chapman's judgment noted that the disallowance was well known in Wellington. 
Lloyd pointed to FitzRoy's speech at the opening of the Legislative Council in Auckland, and argued that the disallowance was effective from the Governor's speech on 9 January. The office of Sheriff under the Supreme Court Ordinance had, he argued, ceased to exist at that point. There was, therefore, no officer with legal authority to detain him in custody. Additionally, no sheriffs had been appointed pursuant to the new ordinance, so the new statute could not provide authority for Lloyd's detention. If Lloyd had been imprisoned for even a moment without legal authority, it was said, that was grounds for the court to intervene; otherwise Lloyd was caught in "perpetual imprisonment". This, it was argued, was repugnant to "British law". Lloyd also argued that the section of the new Supreme Court ordinance that provided for the continuation of "proceedings" commenced under the old ordinance did not apply here, as there were no on-going proceedings. ${ }^{17}$

Boulcott and Stokes argued that there was no formal disallowance of the ordinance recorded in the Gazette. The statute was therefore still in force, and supplied the Sheriff's authority. Even if the 1841 ordinance was repealed or disallowed, they argued, the Governor had the power to appoint a Sheriff under the prerogative, and the disallowance could not remove the Sheriff from an office held under the Governor's prerogative authority. Further, the office of Sheriff was "requested" by other ordinances, and so must continue. Boulcott and Stokes' case, however, centred on the absence of any "proof of disallowance". ${ }^{18}$

Chapman $\mathrm{J}$ held that the disallowance did not take effect until there was a formal public notification, either by proclamation or public notice in the gazette, or in a public newspaper where no gazette existed. Importantly, he treated the governor's prerogative power as coextensive with the power of appointment under the statute; it did not matter that an ordinance provided for the appointment of a sheriff, because the governor had an alternative authority in his prerogative powers. In the newspaper report of the decision, Chapman's words are reported as "other authority". His notes of the judgment refer to the prerogative as a "higher authority". ${ }^{19}$ The suggestion appears

17 Chapman J's notes In the Matter of Lloyd, "Supreme court; sittings in Banco; motions, arguments \& judgments", 1844, HL, MS-0411/014 at 9-11 (notes of arguments) and at 28-35 (notes of judgment, referring to the case as Boulcott \& another v Lloyd. In the Matter of Lloyd a Prisoner). ("Lloyd, Supreme Court notebook"). The case is also reported in New Zealand Gazette and Wellington Spectator (Wellington 24 February 1844) at 3. The Supreme Court Ordinance 1844, s 27 provided "All proceedings which have been commenced in the Supreme Court under the authority of the Supreme Court Ordinance, session II, No 1, and which are still pending and incomplete, shall continue in as full force and effect as if the same had been commenced under the authority hereof".

18 "Lloyd, Supreme Court Notebook", ibid, at 9-10, and 31. Boulcott and Stokes referred to the Charter of New Zealand, which gave the Governor power to "constitute and appoint judges ... and other necessary officers and ministers ... for the due and impartial administration of justice, and for putting the laws into execution"; "Charter for erecting the Colony of New Zealand", enclosed in Lord John Russell to Governor Hobson, 9 December 1840, GBPP (1841) xvii (311) at 32.

19 "Lloyd, Supreme Court Notebook", ibid, at 34; New Zealand Gazette and Wellington Spectator (Wellington 24 February 1844) at 3. 
to have been that the Sheriff could be seen as appointed under the prerogative rather than specifically under the Act. However, Chapman J avoided making a clear finding on the extent of the prerogative, suggesting that the references to sheriffs, and continuation of proceedings clause, in the 1844 ordinance were sufficient to give the Sheriff authority to act. ${ }^{20}$

\section{DISALLOWANCE IN ADMINISTRATIVE CONTEXT - REVIEW OF COLONIAL LEGISLATION}

Lloyd shows the problems that disallowance of ordinances could create in colonies. To place the problem in context, some elements of colonial constitutional law and practice need to be outlined. In a Crown colony, colonial ordinances were made by the Governor with the consent of the Legislative Council (a body appointed by the Governor). The Governor possessed certain powers by delegation under a Charter issued by the Crown, supplemented by Royal Instructions issued by the Crown-inCouncil. The Crown retained the power to disallow any colonial ordinances. In practice most colonial laws came into immediate operation once being passed by the local legislature. By 1840 , however, governors were generally instructed to expressly reserve for London's approval all ordinances that affected Crown prerogative authority, or which strayed into particular subject areas on which a pan-colonial approach was thought wise, particularly relating to issues of family and citizenship (marriage, divorce and naturalisation), issues of imperial trade (Navigation Acts, maritime laws) and various financial measures. ${ }^{21}$

However, the restrictions of Governor's powers were, on one reading, extremely broad. Under the Royal Instructions for the 1840 Charter for New Zealand, the Governor was not to propose or assent to legislation that would increase or decrease "the number, salary, or allowances of any public officers" without prior permission from London. The Instructions also said that no ordinance should take effect until Her Majesty's pleasure was made known "and signified to you, and by you to the inhabitants of the said colony", except for supply ordinances. However, this was immediately followed by a further exception, which authorised the Council to bring ordinances into effect if the delay waiting for approval would cause "serious injury or inconvenience". 22

The 1840 Charter for New Zealand provided that the Legislative Council should not make ordinances "repugnant to the law of England, but consistent therewith so far as the circumstances of [the] colony may admit". The Legislative Council was to conform with all Royal Instructions (that

20 Chapman said he did not need to decide the extent to which the 1841 Ordinance was impliedly repealed by the 1844 Ordinance.

21 David B Swinfen Imperial Control of Colonial Legislation 1813-1865 (Oxford, Oxford University Press, 1970) at 53 and 69-73; "Charter for erecting the Colony of New Zealand", enclosed in Lord John Russell to Governor Hobson (9 December 1840), GBPP (1841) xvii (311).

22 Letters Patent, cl 24, enclosed in GBPP, ibid at 37. 
is, instructions issued by the Queen-in-council). ${ }^{23}$ The Royal Instructions to Governor Hobson provided that any ordinance in breach of the Charter or Royal Instructions was "absolutely null and void to all intents and purposes." 24

It appears that common law, and administrative and judicial practices, provided a gloss to such clauses. The stipulation that invalid ordinances were null and void (that is, void ab initio) cannot simply be taken at face value. Further, in the mid-1840s New Zealand courts treated instructions as political communications; a breach of instructions did not generate a cause of action. The consequences of any breach were primarily for the political sphere, not the courts. ${ }^{25}$ As I will show, the disallowance of colonial legislation was not a matter of clear positive legal rules or criteria that were applied to legislation as it arrived in London. Rather, constitutional, legal and political considerations merged, in ways that may seem unusual to a modern legal eye.

\section{A Scope of Repugnancy Principle was Unclear}

Colonial legislatures were generally empowered to make laws for the "peace, order, and good government" of the colony. By the 1840s that phrase was not seen as a substantive fetter on legislative capacity. ${ }^{26}$ The principle that colonial laws could not to be "repugnant to the laws of England" did provide more of a substantive fetter on colonial legislatures in the 1830s and early 1840 s. $^{27}$

The constitutional law and practice of the British Empire came under new scrutiny in the late 1820 s and 1830s. A series of inquiries into the legal and administrative systems of the West Indies, the Cape Colony, New South Wales, Ceylon and Mauritius, created new professional and academic interest in colonial law. A series of textbooks were published. Disputes over slavery and the

23 "Charter for erecting the Colony of New Zealand", enclosed in GBPP, ibid at 32.

24 Clause 3, Royal Instructions, 5 December 1840, enclosed in GBPP, ibid, at 35.

$25 R v$ Clarke, Supreme Court Wellington, 7 March 1848 per Chapman J and Martin CJ, reported in New Zealander (Auckland, 28 June 1848) at 2. PG McHugh Aboriginal Societies and the Common Law. A History of Sovereignty, Status and Self-determination (Oxford University Press, Oxford, 2004) at 136-137; see also Damen Ward "Civil Jurisdiction, Settler Politics and the Colonial Constitution, circa 1840-58" (2008) 39 VUWLR 497 at 517-521 (Civil Jurisdiction). Discussions about repugnancy in the 1830s and 1840 s did not make legal distinctions between intra vires and ultra vires, or jurisdictional error and errors within jurisdiction.

26 Swinfen, above $\mathrm{n} 21$, at 35-42 and 58-60.

27 On the historical background of the repugnancy principle, see Mary Sarah Bilder "English Settlement and Local Government", in Michael Grossberg and Christopher Tomlins (eds) Cambridge History of American Law: Early America (1580-1815) (Cambridge University Press, New York, 2008) vol 163 at 63 and 67-69. Bilder notes repugnancy was a standard applied to the internal rules of English corporations: Mary Sarah Bilder "The Corporate Origins of Judicial Review" (2006) 116 Yale LJ 502; see also Mary Sarah Bilder "Idea or Practice: A Brief Historiography of Judicial Review" (2008) 20 Journal of Policy History 1 at 6-26. 
perceived opportunity for social economic and legal innovation or experimentation in colonies also generated debate. What much of the debate highlighted was the unsystematic and ambiguous nature of imperial constitutional law. ${ }^{28}$ The repugnancy principle was no exception. ${ }^{29}$ In 1832 , the then Colonial Office Counsel James Stephen complained that the "precise meaning" of the repugnancy rule had never been "distinctly ascertained". In any event, Stephen thought the words "repugnant to the laws of England" were "practically found of little or no value. ${ }^{30}$ Such ambiguity had long been a characteristic of colonial law. ${ }^{31}$ The result was a doctrine characterised by its "utter flexibility". ${ }^{32}$

Nonetheless, particular procedures for judges to engage with legislators over repugnancy were retained in legislation for colonial government during the late 1820s. James Stephen later told Sir Roger Therry (the second Resident Judge at Port Philip) that he had thought a limited form of repugnancy review should be retained in s 22, Australian Courts Act 1828 (replacing the controversial procedures in s 29 , New South Wales Act 1823$)^{33}$ because it gave colonial lawyers pause for thought. Stephen said that the repugnancy standard: $:^{34}$

28 Zoe Laidlaw Colonial Connections, 1815-45. Patronage, the Information Revolution and Colonial Government (Manchester University Press, Manchester, 2005) at 169-195; "First Report of the Commissioner etc. On the Administration of Civil and Criminal Justice in the West Indies" GBPP (1825) xv (157); "Reports of the Select Committee on Transportation" GBPP (1837) xix (518) and GBPP (1837-8) xxii (660); "Report of the Commissioner of Inquiry into the state of the Colony of New South Wales" GBPP (1822) xix (448); "Report of the Commissioner of Inquiry on the Judicial Establishments of New South Wales and Van Dieman's Land" GBPP (1823) x (33); "Report of the Select Committee on the Disposal of Waste Lands" GBPP (1836) xi (512). [Anon], "On the Government of Dependencies" a review of George Cornewall Lewis An Essay of the Government of Dependencies (J Murray, London, 1841) in (1842) 21 The Law Magazine, or Quarterly Review of Jurisprudence at 122-125; John Henry Howard The Laws of the British Colonies in the West Indies (William Henry Bond, London, 1827); Charles Clark A Summary of Colonial Law (S Sweet, London, 1834); William Burge Commentaries on Colonial and Foreign Laws Generally (Saunders and Benning, London, 1838).

29 Swinfen, above $\mathrm{n} 21$, at 33 and 53-77.

30 James Stephen, minute (14 July 1832) National Archives, London (TNA), CO 13/1, fol 273.

31 Bilder "English Settlement and Local government", above n 27, at 67-69.

32 Bruce Kercher "Why the History of Australian Law is Not English" (2004) 7 Flinders Journal of Law Reform 177 at 178

33 Ibid, at 189-191; Ian Holloway "Sir Frances Forbes and the Earliest Australian Public Law Cases" (2004) 22 Law and History Review 209. Under the New South Wales Act (4 Geo IV c 96), s 29, the Chief Justice of New South Wales had been required to certify that any Bill was not repugnant, prior to the Bill being proposed. This effectively gave the Chief Justice a veto power. The Australian Courts Act 1828 (9 Geo IV c 83 (Imp)) removed this requirement, but allowed judges to refer ordinances to the Council for reconsideration (s 22).

34 Roger Therry Reminiscences of thirty years residence in New South Wales and Victoria (Samson Low, Son \& Co, London, 1863) at 317-318. 
... sounds highly constitutional and decorous. ... it may every now and then prevent some egregious absurdity. This is indeed the correct interpretation of the phrase. Whatever is tyrannical or very foolish you may safely call 'repugnant etc'. But what is necessary for the comfort and good government of the colony, you may safely assume to be in perfect harmony with English law.

Stephen told Therry that what mattered was maintaining the "family resemblance" between English and colonial laws. In the context of the procedures in the 1828 Act, this statement stressed the role of the political branches of government in assessing local circumstances. Despite such private comments, Stephen was comfortable with recommending the use of repugnancy as a ground to constrain colonial innovation and experimentation in certain circumstances. As discussed below, throughout the 1830s and 1840s the Colonial Office was willing to use the repugnancy principle as a ground for disallowing local laws that breached wider principles of constitutional propriety, strayed into areas where the Office was determined to maintain a degree of imperial legal conformity, or which limited the ability of the imperial government to supervise the colonial government. ${ }^{35}$ Thus, the Colonial Office's assessment of repugnancy was often reflective of policy and practice, rather than a positive criteria of repugnancy.

\section{B Colonial Office Review of Legislation}

I turn to concrete examples of disallowance below. Here, let me further examine the Colonial Office's role in the review of ordinances. James Stephen was a key figure in this process in the 1830s and 1840s. Stephen was Colonial Office counsel from 1813 to 1834, when he became Assistant Under-Secretary. Promoted to Permanent Under-Secretary in 1836, he continued to play the leading role in review of legislation; the position of legal counsel was left vacant until $1866 .{ }^{36}$ Stephen was confident of his own legal judgment, and capable of more than a little cynicism about the legal views of others, whether counsel for colonisation companies or the Law Officers themselves. ${ }^{37}$ Generally, colonial laws were only sent for a Law Officer's opinion where a definitive view of an ambiguous legal point was required. Reference to other departments tended to delay the review process, which officials generally sought to avoid. ${ }^{38}$ Even so, particular practises could be adopted for different colonies and different subject-matter. ${ }^{39}$

35 Swinfen, above $\mathrm{n} 21$, at 20-36.

36 Ibid, at 21-35. On Stephen's place in the politics of relationships between civil servants and ministers in the mid-1830s, see Laidlaw Colonial Connections, above n 28, at 51-54.

37 James Stephen to George Hope, 14 October 1841, TNA, CO 13/20, fol 111-2; Swinfen, above n 21, at 1030; James Stephen, minute, (circa 8 November 1842), TNA, CO 209/20, fol 176; [James Stephen], draft letter to Law Officers (30 November 1842) TNA, CO 209/17, fol 178.

38 Swinfen, above $\mathrm{n} 21$, at 34 .

39 Ibid, at 38-39. At times in the 1830s and 1840s, review of legislation for some colonies appears to have been haphazard. The Colonial Office depended on colonies sending legislation to Britain promptly, which did not always occur. Colonial Office file-keeping structures and the pressure of other work meant that 
The administrative practice when reviewing colonial statutes did not always match the constitutional theory. Colonial ordinances were, technically, to be reviewed by the Board of Trade, a committee of the Privy Council, of which the Secretary of State for the Colonies was a member. By the 1830s not all colonies were subject to this process. David Swinfen's 1970 study, still the leading text, concludes that New Zealand was one of the colonies that was subject to formal review of legislation by the Privy Council. This process involved making orders-in-council recording any disallowances. However, while the Privy Council certainly approved ordinances at times in the 1840s, I have not located an order-in-council recording disallowances for New Zealand. It may be that, in practice, Colonial Secretaries simply informed governors of the government's decision by despatch, without an order-in-council. For reasons I will come to shortly, it was possible for the British government to, in effect, "disallow" ordinances without having an order-in-council formally issued. ${ }^{40}$

Colonial Office assessments on repugnancy sometimes differed markedly from the views of the English law officers. ${ }^{41}$ In the early 1840 s both Whig and Tory Colonial Secretaries expressed frustration at repugnancy interpretations by the English law officers that restricted the ability of local legislatures to amend evidence laws relating to indigenous peoples. Successive law officers saw the rules about capacity to give evidence as "fundamental" elements of "British jurisprudence"; colonial legislatures lacked the capacity to alter such rules. The issue was eventually resolved by imperial legislation in $1843 .{ }^{42}$

However, questions of court procedure and evidence continued to raise tensions between the law officers and the Colonial Office throughout the 1850 s. ${ }^{43}$ Law officer opinions sometimes appear to

legislation might remain unexamined for some time. For example, Grey to Lord Stanley (16 July 1842) TNA, CO 13/26, fol 325; Gardner to James Stephen (15 February 1843) TNA, CO 13/26, fol 337.

40 See the discussion below. Swinfen, above n 21, at 15-17.

41 George Hope, minute on Law Officers to Lord Stanley (26 October 1842), TNA, CO 18/33, fol 55; James Stephen, minute on Law Officers to Lord Stanley, 8 November 1842, TNA, CO 209/17, fol 176.

42 Colonial Evidence Act 18426 Vict c 22 (Imp); Ann Hunter "The Origin and Debate Surrounding the Development of Aboriginal Evidence Acts in Western Australia in the Early 1840s" (2007) 9 University of Notre Dame Australia Law Review 115; Russell Smandych "Contemplating the Testimony of 'Others': James Stephen, The Colonial Office, and the Fate of the Australian Aboriginal Evidence Acts, circa 18391849", (2006) 10 Legal History 97; Damen Ward "Imperial Policy, Colonial Government and Indigenous Testimony in South Australia and New Zealand in the 1840s" in Dorsett and Hunter Law and Politics in British Colonial Thought, above n 3.

43 In 1856 a Hong Kong ordinance made a witness who "contradicted their own previous evidence" guilty of perjury, regardless of the materiality of the statements; NJ Miners "Disallowance and the Administrative Review of Hong Kong Legislation by the Colonial Office, 1844-1947" (1980) 18 Hong Kong LJ 218, at 228-229. The Law Officers said this was an unacceptable deviation from English law. They resisted Colonial Office requests to reconsider, insisting that the crime of perjury should not be "one thing in Hong Kong and a different thing in the rest of Her Majesty's dominions". As Miners points out, by this time several of the Colonial Office staff had come to the view that such an approach was flawed, and that 
have been more cautious about colonial innovation than officials, but historians lack a proper survey of the relationship between such opinions and Colonial Office actions. It is noticeable, however, that repugnancy was often used by the Colonial Office in relation to legal institutional structures, or procedural rules, and in relation to the coercive authority of Crown officials. Ordinances abolishing grand juries were repeatedly rejected in the 1840s. Evidence laws were a point of contention with several colonies. ${ }^{44}$ The powers of lay magistrates and junior officials were often scrutinised closely. More generally, administrative and judicial discretions were often critiqued in terms of repugnancy. There was a political element to this approach. The Colonial Office, particularly in the 1830s and 1840 s, was attempting to build more formal and robust channels of information-gathering, and seeking to assert the role of the imperial government and colonial governors in setting policy aims in colonies. ${ }^{45}$ British governments were therefore wary of allowing decision-making authorities that they could not ultimately review or advise on through the Governor. Delegated powers for resident magistrates or other officials to make rules or regulations, or powers to levy rates or fees, were often closely reviewed to ensure there was sufficient oversight. ${ }^{46}$

There was an on-going concern to preserve the scope of the prerogative powers of the Crown. In Australasian colonies in the 1830 s and 1840s, this was clearly illustrated in relation to land titles, specifically an increased concern with regulating informal titles, a denial that direct purchase of native title by settlers gave good title against a Crown grant, ${ }^{47}$ and a firm suspicion of any settler attempts to establish formal political institutions or establish political relationships independent of Crown offices and authority, particularly in relation to indigenous peoples. ${ }^{48}$ This broader policy of

colonial legislatures could not be so limited; though the extent of the limit was not settled until the Colonial Laws Validity Act 186528 \& 29 Vict c 63 (UK).

44 See Smandych, above n 42.

45 Laidlaw Colonial Connections, above n 28

46 Miners, above $\mathrm{n} 43$, at 220-230.

47 AGL Shaw "British Policy Towards the Australian Aborigines, 1830-1850" (1992) 25 Australian Historical Studies 265 at 273-283; James Stephen to Smith (28 July [1840]), TNA, CO 209/4, fol 343. In $R v$ Symonds, above n 2, the Court held that Mr Symonds, whose only title to the land in question was by virtue of a Crown grant, held better title than Mr McIntosh, who had purchased directly from the Māori owners pursuant to a certificate from Governor FitzRoy waiving the Crown's pre-emptive rights. The Court in $R v$ Symonds held that the Governor had no ability to waive the prerogative, that the Crown was the source of all title in the colony, and that no title could pass from the Crown to a subject except under the colonial seal. Mr Symonds' title therefore prevailed. See also, Hickford "Vague Rights", above n 2.

48 See, for instance, Governor Hobson's alarm at the Wellington settlers appointing their own magistrates (who then arrested and imprisoned other British subjects) prior to the announcement of British sovereignty: Hobson to Shortland (23 May 1840), HL, MS0052/4; James Stephen, memoranda (16 September 1839), (24 October 1839), TNA, CO 209/4, fol 571-2, 577-9. The rejection of 'Batman's Treaty' in Port Philip may also be seen in this light: the Colonial Office rejected the suggestion that the Crown's prerogative ability to forbid the establishment of a new colony depended on any direct dealings regarding property rights in the territory: Bain Attwood Possession. Batman's Treaty and the Matter of History (Melbourne, The Miegunyah 
consolidating Crown authority could manifest in other ways. The Colonial Office, for instance, insisted that the prerogative authority over lighthouses had to remain with the governor, and could not be allowed to pass to the first municipal corporations in New Zealand. ${ }^{49}$

Successive Colonial Secretaries, and their officials, appear to have viewed decisions about repugnancy, and the adaptation of English law to colonial circumstances such a decision involved, as requiring a political judgment. ${ }^{50}$ Reviewing the original New Zealand Supreme Court Ordinance, Stephen wrote that: ${ }^{51}$

Englishmen colonizing new Countries are often said in popular language to carry the Law of England with them. So far as this means that they are to live under a system of Govt, and in the enjoyment of Franchises as like to those of England as the dissimilarity of the two cases will allow, it is a maxim at once intelligible and wise. But when the meaning is carried so far as to imply the adoption of all our Laws.... the result invariably is utter confusion... and an extent of arbitrary and undefined power in the hands of Judges, which is one of the practical grievances of Social Life.

This comment was in the context of reviewing early New Zealand legislation that departed from existing English law and practice. Stephen was defending the value of legislative innovation; although he went on to recommend that several ordinances be disallowed, he was arguing that legislation should be seen the primary means of addressing local circumstances, and that local legislation was a matter for political assessment. Stephen thought that judges were skilled at determining "what the law was", but in assessing the appropriate adjustment required to meet local circumstances, he thought a judge "invariably, an ignorant or ill-informed Arbiter in such matters". 52 This concern with legislation as the key means of assessing how a British "system of government" should develop in settler colonies appears to have been a standard view within the Colonial Office in the $1840 \mathrm{~s} .{ }^{53}$ The desire to ensure that governors were the central figures in the design of colonial government institutions reflected a deep concern about the potential instability of colonial society, and the considerable political and economic cost that might be incurred by Britain

Press, 2009) at 14-101. For a similar approach regarding early South Australian proposals, see James Stephen, memorandum (14 July 1832), TNA, CO 13/1, fol 269-76.

49 Lord Stanley to Hobson (9 January 1843), TNA, CO 209/14, fol 414; Shaw, above n 49, at 273.

50 Minutes on Grey to Lord Stanley (16 July 1842), TNA, CO 13/26, 325-35, fol 339-40; Swinfen, above n 21 , at 20-35; Minute (15 February 1843), TNA, CO 13/26, fol 337; Shaw, above n 47, at 269-273.

51 James Stephen to Lord Stanley (29 September 1842), TNA, CO 209/14, fol 360-2.

52 Ibid.

53 Lord John Russell to Governor Hobson (9 December 1840) GBPP (1841) xvii (311) at 36; James Stephen to Lord Stanley (29 September 1842), TNA, CO209/14, fol 361; See Damen Ward "Constructing British Authority in Australasia: Charles Cooper and the Legal Status of Aborigines in the South Australian Supreme Court c. 1840-186" (2006) 34 Journal of Imperial and Commonwealth History 483 at 491. 
if colonisation was mismanaged. Importantly, British administrators well understood a distinction between annexation and colonisation. ${ }^{54}$ Annexation provided the legal foundation for colonisation. Colonisation was a process to be managed across time and space, and governors were expected to try to control the pace and location of that process. ${ }^{55}$ Governors were therefore expected to consider the wider interests of the colony (as they judged them) rather than the particular ambitions or "party interests" of settlers or, indeed, the perceived interests of indigenous peoples. ${ }^{56}$

This political sensibility played a role in the disallowance of Supreme Court Ordinance itself. ${ }^{57}$ The New Zealand Supreme Court Ordinance 1841 was considered by the Colonial Secretary, Lord Stanley, as part of bundle of 19 New Zealand ordinances. James Stephen prepared a briefing for his minister. He noted the New Zealand administration's desire to free the colony from many of the perceived constraints and technicalities of English law. Stephen thought this wise, but fraught with dangers for legal certainty. He also felt the laws indicated a "morbid propensity for interfering into everything" by the colonial government. ${ }^{58}$

On the Supreme Court Ordinance, Stephen identified sections that went further than officials thought prudent, or which potentially limited the prerogative authority either of the imperial Crown or of the Governor. Lord Stanley chose to disallow the Ordinance. He listed a number of reasons; not all related expressly to repugnancy. The Supreme Court Ordinance, he wrote, allowed judges and court officials powers of appointment and fees-setting that were better kept under the Governor's direct control (and, therefore, under London's ultimate supervision). The ordinance did not clearly signal that colonial judges were appointed by the Crown on Her Majesty's pleasure. Colonial Sheriffs should not have the traditional "Political Functions" of an English sheriff, particularly the power of convening public meetings of freeholders. Further, the abolition of grand juries in all criminal cases was seen as repugnant to English law, because it interfered with the right to trial by jury. ${ }^{59}$

54 Ward, ibid, at 490-493; Lord Stanley to W Shortland (21 June 1843) GBPP (1844) xiii (556), appendices at 475; Bilder "English Settlement and Local Government", above n 27, at 65-66.

55 Hobson to Shortland, 24 July 1840, HL, MS 0052; James Stephen (26 February 1846), minute on FitzRoy to Lord Stanley (16 August 1845), TNA, CO 209/35, fol; 47. Ward "Constructing British Authority in Australasia", above n 55, at 490-493; Lord Stanley to W Shortland, above n 56.

56 Ward "Constructing British Authority in Australasia", above n 53, at 490-493. Lord Stanley to W Shortland, above $n 54$.

57 Lord Stanley to FitzRoy (31 January 1843), ANZ, G1/7; Minutes by George Hope and James Stephen on Law Officers to Lord Stanley (8 November 1842), TNA, CO 209/17, fol 176.

58 James Stephen to Lord Stanley (29 September 1842), TNA, CO 209/14, fol 360; On similar local complaints see New Zealand Gazette and Wellington Spectator (Wellington, 31 May 1843) at 2.

59 James Stephen to Lord Stanley (29 September 1842), TNA, CO 209/14, fol 360-4. 
However, the Law Officers had initially seen little of real concern with the Ordinance. Stephen's repeated complaints (and concern by George Hope, the junior minister, that the original letter had not clearly explained the issues) led to a second opinion. This did little to reduce Stephen's objections. The Law Officers admitted they knew little of how colonial courts were constituted, and the appropriate structures for colonial institutions. They were cautious about the grand jury reforms, but willing to admit that it might be justified if communication or transport was limited. Ultimately, it was Stephen's analysis that seems to have been endorsed by Lord Stanley. ${ }^{60}$

\section{Confirming, Disallowing or "Leaving to their Operation"}

Review of an ordinance was not simply a matter of allowing or disallowing it. An ordinance would usually take effect from its assent by the Governor, unless specifically reserved for consideration by the imperial government. This meant that positive "confirmation" was usually not necessary for the law to have legal effect. Most New Zealand ordinances were simply "left to their operation" by the British government; neither confirmed nor disallowed, but left to run. On occasions, the Colonial Secretary could decline to support a colonial law and indicate that the Governor should review part or all of the law (without any suggestion of, or reference to, "disallowance"). This approach was intended to limit political embarrassment and administrative difficulties for the Governor. It allowed some degree of local solution to the issue. ${ }^{61}$ In 1845 the Colonial Office objected to a Hong Kong ordinance that allowed the branding, imprisonment and banishment of members of criminal gangs. There was no disallowance, however, because of the "very serious embarrassment" such a step might pose to the administration in the political context of the time. Instead, immediate amendment was ordered. ${ }^{62}$ Similarly, in 1848, the Colonial Secretary, the Earl Grey, reviewed a New Zealand ordinance restricting the purchase of liquor by Māori. The law was arguably a breach of the Governor's Royal Instructions, because it created criminal penalties for Māori that did not apply to settlers. Earl Grey decided that the "peculiar provisions" of the ordinance meant it could not be positively confirmed; it was simply "left to its operation". ${ }^{63}$

60 Hope, minute on Law Officers to Lord Stanley (8 November 1842), TNA, CO 209/17, fol 176; Law Officers to Lord Stanley (29 November 1842), TNA, CO 209/17, fol 182; Minute and draft letter, [30 November 1842?] TNA, CO 209/17, fol 178 (querying whether abolishing grand juries was "so great an innovation on the principles of the English law" as to exceed the powers of the Legislative Council).

61 Accordingly to Swinfen, the Colonial Office preferred not to formally confirm ordinances by order-incouncil because that meant any subsequent amendment or change also had to be confirmed by the same means. Swinfen, above n 21, at 36-37.

62 Miners, above $\mathrm{n} 43$, at 221-222.

63 Earl Grey to Grey (23 February 1848) GBPP 1847-8 xliii [1002] at 134; see Clause 15 of the Royal Instructions of 1840, enclosed in Lord John Russell to Governor Hobson (9 December 1840) GBPP (1841) xvii (311) at 36. 
Colonial Secretaries knew that Crown Colony governors could legislate quickly if they needed to, and they knew that a disallowance might not be announced at the same time that replacement legislation was proposed. ${ }^{64}$ Instructions on the disallowance of ordinances were often framed as a matter of political instruction, with an awareness of the practicalities of communication. In 1843, for instance, the Western Australia Governor was encouraged by Lord Stanley, to re-enact an ordinance that had been disallowed for being repugnant to "fundamental" British law on testamentary capacity. Lord Stanley intended to propose imperial legislation that would authorise colonial legislation altering the issue, and he encouraged Governor Hutt to pass a new ordinance in expectation of the imperial Act being passed. The re-enacted ordinance was passed before news of the imperial Act reached the colony. The new ordinance was not sent to London for review. ${ }^{65}$ When Governor Grey abolished the Auckland Court of Requests by executive order in 1847, the Colonial Office agreed that he had overstepped his authority, but noted the Governor had issued the order in anticipation of legislation, and that the Legislative Council would probably have resolved the issue by the time any despatch reached Auckland. ${ }^{66}$

In the case of the Supreme Court Ordinance, Lord Stanley instructed FitzRoy not to disallow the ordinance until three months after receiving the despatch. This was done to avoid any "inconvenience" that an "abrupt announcement" might cause. The Colonial Secretary noted that in the "interval" an amendment "Act" could be passed. ${ }^{67}$ This reinforces a point made above: despatches were political communications. On occasion in the 1840s Chapman J and Martin CJ treated the Governor's discretion about how to respond to a despatch as a broad political discretion, even on a disallowance issue. ${ }^{68}$

However, on receiving the disallowance despatch, FitzRoy was unsure of how best to respond. The despatch was referred to the Attorney-General with a query as to whether the Governor could "legally" delay announcing the disallowance. ${ }^{69}$ The response appears to have been to proceed to a new ordinance as soon as possible.

64 Rogers to Merivale (4 November 1852) TNA, CO 323/72, fol 447-53 at 450.

65 Ann Hunter "Aboriginal Evidence Acts in Western Australia", above n 42, at 115-145.

66 Merivale, minute (23 September 1848), TNA, CO 209/59, fol 440.

67 Lord Stanley to FitzRoy (31 January 1843), ANZ, G1/7.

68 See $R v$ Clarke, above n 25; $R v M^{\prime}$ Donald, above n 2. McHugh Aboriginal Societies and the Common Law, above n 25, at 136-137; see also Ward "Civil jurisdiction", above n 25, at 517-521.

69 The Attorney-General's reply has not been located; FitzRoy (26 September 1843) minute on Lord Stanley to FitzRoy (31 January 1843), ANZ, G1/7. 


\section{Proclamations of Disallowance}

In Lloyd, Chapman asserted that a proclamation was necessary for a disallowance to take effect. In many ways this was a practical rule to apply to a colony with several settlements at a distance from each other. But what was the basis in practice and law for Chapman's decision? I am not aware of a case in the decades immediately prior to Lloyd that considered when disallowance of a colonial ordinance took effect. It seems that in pre-revolutionary America the practice was that disallowance was effective from promulgation in the colony. ${ }^{70}$ Some statutes and charters for other colonies required proclamations for any disallowance to take effect. ${ }^{71}$ The Royal Instructions to Governor Hobson did not directly address this point.

What can we tell from the Colonial Office practice? In 1845, Lord Stanley told Governor Grey to proclaim the allowance of ordinances "in the usual and most authentic manner". ${ }^{72}$ This suggests that a proclamation was considered standard for announcing the final enactment of ordinances. It may also indicate a practice for ordinances generally. ${ }^{73}$ Scholars of Hong Kong colonial law have concluded that the proclamation approach applied in that colony from the 1840s, even though it was not explicitly part of that Colony's Charter until $1877 .{ }^{74}$ The Australian or Canadian practice in the 1840s remains unclear.

There is no indication in the judgment that Chapman thought his approach was unusual. He prided himself on his knowledge of colonial law, and had plans to write a textbook. Had he felt he was deciding a controversial or unclear point, he probably would have promoted the decision to friends and family in London, as he did with other cases. ${ }^{75}$ Further, the newspaper editors of the time did not remark on Lloyd, despite the close interest newspapers took in court proceedings. All of this suggests Chapman's decision was not a radical one. However, it is difficult to be certain, because imperial constitutional law remained largely a matter of unsystematised law and practice.

70 Arthur P Scott "The Constitutional Aspects of the "Parson's Cause" (1916) 31 Political Science Quarterly 558 at 574-575; Dudley Odell McGovaey "The British Privy Council's Power to Restrain the Legislatures of Colonial America: Power to disallow statutes: Power to Veto" (1945-46) 94 U Pa L Rev 59 at 59-92; Enid Campbell, "Colonial Legislation and the Laws of England" (1964-7) 2 U Tas L Rev 148 at 148-175.

71 See for example the "Draft order-in-council for establishing representative institutions for the Cape" (25 January 1851) enclosed in HG Smith to Earl Grey (21 January 1851) GBPP (1851) xxxvii [1362] at 132.

72 Lord Stanley to Lt-Governor Grey (13 August 1845) GBPP 1846 v (337) at 81-82.

73 Proclamations were a standard instrument of government; ordinances sometimes provided that they would only take effect in particular regions in colonial New Zealand on proclamation. The disallowance of provincial ordinances by the general government under the 1852 constitution was effected by proclamation.

74 Miners, above n 43, at 218, 220; Christopher Munn Anglo-China, Chinese People and British Rule in Hong Kong, 1841-1880 (Hong Kong University Press, Hong Kong, 2001) at 62.

75 HS Chapman to H Chapman (22 February 1848) and (17 April 1848) (postscript) Alexander Turnbull Library, Wellington (ATL) qMS-0419. 
The most detailed indication of Colonial Office practice comes well after Lloyd. In 1852 a question similar to that in Lloyd arose in relation to an ordinance from Mauritius. The Governor declined to proclaim the disallowance of an ordinance on liquor taxes. One Colonial Office official, Fredric Rogers, insisted there was a well-established imperial practice requiring promulgation to bring disallowance into effect. Disallowance, he thought, was a "quasi-legislative" act that needed public promulgation to have legal effect. ${ }^{76}$ The Departmental Under-Secretary, Herman Merivale, consulted James Stephen (now retired). Stephen took a different view to Rogers. According to Merivale, Stephen felt that disallowance took effect on the arrival of the despatch in the colony; the Governor could not simply ignore the disallowance and thereby set imperial oversight at nought. While Rogers focussed on the practical inconvenience to those affected by a disallowance, Stephen was concerned with the practical implications for imperial administration. Stephen also offered a technical analysis, noting that the Governor's Royal Instructions and the Charter for Mauritius did not require the Governor to publicly advise disallowances. ${ }^{77}$ The Colonial Secretary, Sir John Pakington, decided that the disallowance took effect when the despatch arrived in the colony. The Governor was informed that this was the correct position. The 1852 controversy shows the significance of institutions and institutional practice in understanding the structure of colonial law. ${ }^{78}$

\section{PREROGATIVE AUTHORITY IN THE COLONIAL CONSTITUTION}

Stephen's concern with ensuring effective oversight of colonial administrations brings us back to the treatment of the Governor FitzRoy's speech in Lloyd. Lloyd's case illustrates an important theme touched on in other decisions by Chapman in the 1840s; a tendency to protect an extensive Crown prerogative authority as a potential alternative source of authority to local ordinances. ${ }^{79}$ Chapman's comment that prerogative was an available source of authority independent of the ordinances made by the Governor-in-Council is a reminder of the centrality of the Governor and the prerogative in the colonial constitution. I have written elsewhere of a strand of British legal and political thought in the

76 To Rogers, disallowance of a colonial ordinance was not analogous to the Crown withholding assent; an ordinance was not an inchoate law that required some further step to confirm it, because (most) ordinances took effect once passed. Disallowance was therefore a "quasi-legislative" act. "Established principles of jurisprudence" required that there should be a public promulgation Rogers to Merivale (4 November 1852), TNA, CO 323/72, fols 447-453 at 450; see also Swinfen, above n 21, at 41-42. Note also Chapman's reference to "repeal" in Lloyd itself.

77 Staff noted that a similar issue had occurred in the past in Hong Kong but that the situation then had simply been "passed over".

78 It is unclear, however, whether this approach became known as the orthodox position: William Forsyth Cases and opinions on Constitutional Law (Steven and Haynes, London, 1869) at 30, said that disallowance took effect on publication in the colonies.

79 See, for instance, $R v$ Clarke, above n 25; White $v$ Richmond Supreme Court Nelson, 7 April 1848 per Chapman J, reported in Nelson Examiner (Nelson, 15 April 1848) at 27. 
1840s that stressed the need for a strong and extensive prerogative authority to deal with the challenges of founding and running new colonies. ${ }^{80} \mathrm{~A}$ colony, as one sacked South Australian governor tried to explain to the Colonial Office, was like a boat passing through rapids - it need a clear, undisputed, captain at the helm. ${ }^{81}$ Such ideas tended to stress the constitutionally inferior status of colonial polities. ${ }^{82}$

Several cases indicate Martin and Chapman's willingness to acknowledge the potential breadth of the prerogative authority in a Crown colony setting, and their insistence on appropriate legal form and process in legal proceedings. These factors constrained the extent to which litigants could give legal expression to their economic, social or political claims. In Clarke, both judges stressed that the Governor's power to make Crown grants originated in the Crown Charter, not in local ordinances or imperial statute. They emphasised that clear and unambiguous statutory language was needed to restrict the extent of prerogative authority. The Land Claims Ordinance, on their approach, did not restrict the ability of the Governor to grant in excess of the maximum size that the Commissioners could recommend under the Ordinance. As Mark Hickford has explored, the court also emphasised the various formal requirements of grants, the point relied on by the Privy Council on appeal. ${ }^{83}$ Chapman's concern with such formal requirements (present in Lloyd) can be seen elsewhere. In 1844, for instance, he refused to follow the local County Court practice of allowing all Māori unsworn testimony and insisted that the common law tests as to competency had to apply. ${ }^{84}$ Further, in 1848, Chapman and Martin each declined separate applications designed to challenge Governor Grey's suspension by decree of the Court of Requests. ${ }^{85}$ Both the Court of Request cases stressed the "appropriate" bounds of judicial supervision of inferior officials, and the need for applicants to comply with established English precedent.

Chapman took such approaches despite his private views about the "despotism" permitted by Crown Colony government. ${ }^{86}$ The approach of the judges in these cases does not reflect a "subservience" to the executive, but a measured assessment of, as they saw it, the particular sphere

80 Ward "Civil Jurisdiction", above n 25, at 517-19.

81 G Gawler The present state of the moral principle in the supreme government of the British colonial empire described in a petition which was left for presentation to Her Majesty on the $3 d$ [sic] July, 1850 (G Barclay, London, 1850) at 3-4. Gawler was recalled for issuing unauthorized Treasury bills.

82 Ward "Civil Jurisdiction", above n 25, at 511-512.

83 Hickford "Important Principles", above n 2.

84 Chapman J "Address to the Grand Jury, Wellington" (17 April 1844) reported in New Zealand Gazette and Wellington Spectator (Wellington, 1 May 1844) at 2.

85 Graham v Tye Supreme Court Auckland, 16 February 1848 per Martin CJ, reported in New Zealander (Auckland, 19 February 1848) at 2; White v Richmond, above $\mathrm{n} 79$. See the discussion of these cases in Ward "Civil Jurisdiction", above n 25. 
of legal and judicial action and analysis, and the nature and bounds of gubernatorial authority. ${ }^{87}$ Chapman appears to have been happy to consider reception of law questions where he thought they arose directly and appropriately in a particular case. Indeed, he thought that reception cases were the "pleasantest as well as the most important" of his judicial function. However, for Chapman the sphere of legal adjudication was constrained by the particular procedural requirements of the law, and the particular scope of whatever writ or remedy was sought. ${ }^{88}$

This exploration of 1840 s cases suggests the relationship between imperial and colonial laws and law-makers involved a more complex set of questions and approaches than simply considering the extent of "local circumstances". Questions about whether English statutes prevailed over local practice might well be treated differently to whether common law prevailed over local practice, or whether local legislation might be disallowed. Thus, judicial approaches are not explained simply by a reference to "pluralism" or "positivism". ${ }^{89}$ Chapman's extra-judicial writing indicates that he saw the possibility and the necessity of colonial divergence and development from English law. But he did not simply adopt local practice. He expected a careful application of the English law in light of local legislation and the relevant facts as proved. In the 1840s he was careful to rehearse the relevant precedents and his approach showed a concern with identifying the relevant legal rule from the case law cited to him. ${ }^{90}$

\section{A Chapman's 1854 Article on Repugnancy}

By looking at Chapman's later writings on repugnancy, we can place Lloyd in a wider narrative of constitutional change - one that centres on the shifting scope of colonial legislative authority. In 1854, Chapman published an article on repugnancy in the London Law Magazine. He complained that the "true intent and meaning of" repugnancy clauses in charters was "ill understood". He sought

87 Chapman told his father that Governor Grey was surprised by the result in Clarke, because Grey expected "a little" of the "subserviency" often shown to governors by officials. Chapman prided himself on, amongst other things, his independence of character: HS Chapman to H Chapman (24 August 1849), ATL, qMS0419 .

88 HS Chapman to H Chapman (17 March 1849), ATL, qMS-0419. See also note 91 below.

89 See also Kercher's discussion of Burton J and Forbes CJ on repugnancy in "History of Australian Law" above $n$ 32, at 189-191 and 194-196.

90 HS Chapman to H Chapman (17 March 1849), ATL, qMS-0419; Chapman J "Address to the Grand Jury, Wellington" (17 April 1844), above n 84; White $v$ Richmond, above n 79; "Lloyd, Supreme Court notebook", above n 17 at 32-34; Henry Samuel Chapman "What law does a New Colony take" ATL, MSPapers-0053-6; Samuel \& Joseph v Carkeek (Collector of Customs) Supreme Court Wellington, 29 September 1851, available at New Zealand's Lost Cases <www.victoria.ac.nz/law/nzlostcases>. I find little in Chapman's early decisions to suggest a greater influence of non-positivist jurisprudence compared to his subsequent decisions. McHugh Aboriginal Societies, above n 25, at 40-41; see also Martin CJ "Address to the Grand Jury, Supreme Court Auckland" (4 March 1844) in "Reports of cases in the Supreme Court of New Zealand at Wellington and a few at Auckland. Collection No 2", HL, Chapman Pamphlets v 104/41 at 1: "we may not depart or swerve from the rule of English law; we must be content to grow up to it." 
to limit the scope of the doctrine. Chapman stressed the practical need for colonial legislatures to amend English law, providing it did not clash with British statutes that were intended to regulate colonial affairs. ${ }^{91}$

By 1854 many of the settler colonies had representative institutions - the centre-piece of a liberal settler vision of the constitution that Chapman had long privately favoured. Settler legislatures generally insisted they were best suited to judge local circumstances. The political acknowledgement of legislative capacity eventually pushed constitutional acknowledgement along with it, broadening the parameters of permissible legislation. Of course, this did not occur without conflict or tension; it was by no means a smooth process in any colony. ${ }^{92}$ The tension between emerging norms of responsible government and older traditions of extensive imperial Crown and gubernatorial authority is apparent in Chapman's article. Chapman treated colonial statutes that impinged on the prerogative as a distinct category. The Crown "was universal" and the prerogative common to all colonies. Colonial statutes that were "repugnant to the prerogative" were "void ab initio". Assent to such statutes ought to have been reserved for confirmation in London, and if the Governor "through inadvertence or otherwise" gave assent in the colony, Chapman thought there was "little doubt" that such a law was void "until the Queen's assent be signified". 93

There was an important shift in Chapman's formulation. The standard against which colonial variation was measured was no longer described as "the laws of England" but "the prerogative". This potentially gave the colonial legislature greater capacity. Chapman's article was largely concerned at defining repugnancy in a way that acknowledged the practical reality of law-making in colonies that were far from Britain. However, his examples still showed the difficulty of confining or systematising repugnancy. Chapman gave the example of a statute he said restricted the prerogative of mercy by barring conditionally pardoned men from entering Victoria. The Governor had assented to the Act. Chapman argued that the Act was clearly of the sort the Governor was obliged to refer to London without local assent. Chapman said the Act was therefore void from the outset. Yet by stressing that the ordinance was void ab initio Chapman's approach itself suggested the possibility of a restrictive reading of colonial legislative capacity that might draw judges into conflict with newly confident settler legislatures. (As is well known, such conflict occurred in South

91 [HS Chapman], "On the Doctrine of Repugnancy in Relation to Colonial Statutes" (1854) 51 The Law Magazine or Quarterly Review of Jurisprudence 1. See also [HS Chapman] "Points of Colonial Law. Revocation of Powers of Attorney by the Death of Principal" (1854) 51 The Law Magazine or Quarterly Review of Jurisprudence 185. On Chapman's authorship, see the postscript to Henry Samuel Chapman "What law does a New Colony take", above n 90.

92 John Manning Ward "The Responsible Government Question in Victoria, South Australia and Tasmania, 1851-1856" (1978) 63 Journal of the Royal Australian Historical Society 221.

93 [Chapman], "Repugnancy", above n 91, at 7-9. 
Australia at the end of the 1850 s when Justice Boothby insisted on a narrow reading of colonial legislative capacity). ${ }^{94}$

In his article, Chapman cautioned the reader that he was not concerned with decisions by the Secretary of State to disallow a colonial law "for violating the general spirit and policy of the law of England". 95 This was often described as part of "repugnancy", he said, but was a "loose and vague use of the word ... altogether different from that sort of repugnancy which would operate to make a colonial enactment void ...". Chapman's description tried to confine repugnancy to particular questions about the subject-matter of the local law in light of the governor's authority, and to questions about the compatibility of colonial law with imperial statutes. The prerogative was treated as a category of legal authority that explained the governor's authority to give local assent. The imperial Crown's authority (directed by British ministers) to disallow on general policy grounds was treated as a separate category.

Yet Colonial Office officials in the 1840s did not distinguish so starkly between legal, constitutional and political factors in their analysis. Chapman's desire to make such a distinction probably reflects various political attempts to establish and consolidate the power of representative legislative bodies in the late 1840s and 1850s. That process constrained, in practice, the independent prerogative powers of governors and the British government. Governors' independent discretions were reduced, often by reaching agreements that distinguished between different types of gubernatorial decisions or powers. This was an intensely political process; it did not necessarily lend itself, to the clear categories Chapman sought to establish. Nonetheless, the assertion of authority by settler legislatures, over time, produced a change in the understanding of how repugnancy ought to operate. As noted, this was by no means a smooth, uncontroversial shift. The controversy over Justice Boothby's decisions in South Australia were, in large part, the product of that judge's idiosyncratic refusal to reconcile notions of colonial legislative authority with the emerging constitutional practices of responsible government. ${ }^{96}$ By seeing Lloyd and Chapman's writings against these contexts, we can see the considerable potential for New Zealand legal history to engage with larger narratives of British and imperial history.

Cases like Lloyd should matter to historians. Such cases provide insight about the institutional structure and practice of colonial government. Such cases are building blocks on which more general histories must rely. Keith Sinclair famously argued that New Zealand historical writing needed a "generation of pedants"; a network of scholars whose engagement with the detail of the

94 John M Williams "Justice Boothby: A Disaster that Happened" in George Winterton (ed) State Constitutional Landmarks (Federation Press, Sydney, 2007); "Correspondence between the Governor of South Australia and the Secretary of State Relative to Mr Justice Boothby" GBPP (1862) xxxvii [3048].

95 [Chapman] "Repugnancy", above n 91, at 10.

96 Williams", above n 94; Correspondence between the Governor of South Australia and the Secretary of State Relative to Mr Justice Boothby GBPP (1862) xxxvii [3048]. 
colonial archives would test the assumptions of broader studies. ${ }^{97}$ Such foundational work is still required in New Zealand legal history. Both Lloyd's case and Chapman's extra-judicial writing suggest that historical accounts of the law may need to be wary of replicating modern categories and maxims. "Repugnancy" was not a stable, settled body of legal principle. Disallowance for repugnancy was shaped by a range of political factors and mechanisms. Chapman's treatment of colonial legislation in Lloyd, and elsewhere, indicates a complexity to reception of law jurisprudence and practice that is not adequately captured by simply referring to a "local circumstances" principle or rule.

97 Keith Sinclair The Māori Land League: An Examination into the Source of a New Zealand Myth (Auckland University College, Auckland, 1950) at 3. A similar call has recently been made in relation to current historiography, though by reference to very different methodological frameworks to that of Sinclair: Tony Ballantyne "The State, Politics and Power, 1769-1893" in Giselle Byrnes (ed) The New Oxford History of New Zealand (Oxford University Press, Melbourne, 2009) 99 at 100; Damon Salesa "New Zealand's Pacific" in ibid, 149 at 150 . 